\section{Crucial structures}

\author{
Julie Farseth Berg
}

\section{ACCIDENT}

I did not know much about knee injuries before I got one in 2018. I was only 12 years old when I injured my knee. My homeplace is a city in the northern part of Norway, and I live together with my parents and two older siblings. We all like to be active and participate in sports. I was, and still am, active as a gymnast. I train 3 hours a day, five times per week. You could say that I have grown up in this gymnastics hall. When I got injured, I was just about to start seventh grade which was my final year in primary school. Besides school and training, I liked being active with friends during my spare time.

The injury occurred during gymnastics practice. I was working on a routine in the horizontal bar. I had just let go of the bar and landed in a pit filled with pieces of foam. The lower part of my body landed vertically down in the pit and was stuck there, but the upper part continued in the horizontal/forward direction, and this ultimately led to a rotation in the left knee. I felt pain immediately, but had experienced several similar episodes before, and did not think much more about it then and there.

My father, who is a physiotherapist, picked me up from practice, and I walked out on my own. The next day after we visited a general practitioner who examined me and referred me for an MRI scan, which was taken 4 days after the injury. The scan showed that I had an anterior cruciate ligament (ACL) injury as well as a medial meniscus injury. One week later I had surgery for a ruptured meniscus, but the ACL ligament was not reconstructed.

\section{IMPORTANCE OF A GOOD SUPPORT SYSTEM}

I think that the most important factor for me was qualified expertise nearby for the post-surgery follow-up, especially my father. During the first week I went to the hospital a couple of times for check-up.

Correspondence to Dr Julie Farseth Berg, Akershus University Hospital, Lorenskog 0468, Norway; julie.farseth.berg@icloud.com
Almost immediately I started training again. The first three sessions were done in a specialist physiotherapist studio, while for the further follow-up the physiotherapist came to my gymnastics hall in order to aid and guide me in what to do and what not to do. This was perfect, because it made it possible to adapt the rehab to my gymnastics training from the very beginning. Another positive effect of this was that I was able to stay in the same milieu, and talk to my friend and hang out with them just as much as before. My father helps and aids at home just as much as in the gymnastics hall.

\section{TRUST AND WORRIES}

After experiencing this kind of injury, I think that I am a bit more careful than before. I take precautions, especially in the everyday activities outside of gymnastics. For example, I am careful when skiing and I when playing football with friends. I trust my knee, but I still experience moments of insecurity. The knee sometimes gives me discomfort, but I am not worried about getting back in to the game. With having the goal to someday become a professional athlete, it is easier to drop leisure time activities and prioritize training. Even so, it has been hard not to be able to hang out with my friends. For example, I've missed out on jumping on the trampoline and I could not go swimming all summer, not even when I went on holiday with my family. I ended up sitting inside a lot playing video games.

\section{GOALS FOR THE FUTURE}

Six months after the injury I was back on four out of six apparatuses. After just a short period of time I could take part in some of the training with the rest of the group, with only small adjustments (eg, pommel horse and parallel bars without doing the dismount). One year later I can do everything I want to and have no restrictions. I have spent a lot of time in the gymnastics hall, but a substantial part of this has been strength and stability training. My father has been following up under direction from the originally assigned physiotherapist. I hope to take part in a competition again soon, and also begin at a new secondary school where sport is included in the timetable. In the long-term I want to represent Norway in the Olympic Games.

\section{WHAT IS THERE TO LEARN FROM THIS STORY?}

It is important that clinicians never forget the patient's perspective. Patients will always have a unique experiential knowledge about their illness or injury that clinicians are unable to understand on their own. ${ }^{1}$ This is extra important when the patient is a child. One can get quite different aspects on the table when the patient is asked about hopes, concerns and outcomes, than one will get by just looking at objective, observable results of treatment. The gold standard treatment for a certain condition might not be the most helpful for that particular individual. And that is important, because it can change the way we address a clinical problem. After all, the patient's satisfaction is what we should be aiming for.

\section{Collaborators Guri Ekås.}

Funding The author has not declared a specific grant for this research from any funding agency in the public, commercial or not-for-profit sectors.

Competing interests None declared.

Patient consent for publication Parental/guardian consent obtained.

Provenance and peer review Not commissioned; internally peer reviewed.

(C) Author(s) (or their employer(s)) 2020. No commercial re-use. See rights and permissions. Published by BMJ.

$$
\text { (A) Check for updates }
$$

To cite Berg JF. Br J Sports Med 2020;54:560.

Accepted 17 November 2019

Published Online First 11 December 2019

Br J Sports Med 2020;54:560.

doi:10.1136/bjsports-2019-101459

\section{ORCID iD}

Julie Farseth Berg http://orcid.org/0000-0001-86459979

\section{REFERENCE}

1 Staley K. "Researchers don't know what they're missing" - the impact of patient involvement in research, 2018. BMJ. Available: https://blogs.bmj.com/ bmj/2018/11/28/researchers-dont-know-what-theyremissing-the-impact-of-patient-involvement-in-research/ 